\title{
KECEMASAN NARAPIDANA KASUS PEMBUNUHAN PADA LEMBAGA PEMASYARAKATAN KELAS I SEMARANG
}

\author{
Vrimadieska Ayuanissa Waluyan, Suharso \\ Program Studi Bimbingan dan Konseling, Universitas Negeri Semarang \\ e-mail: suharso@mail.unnes.ac.id
}

\begin{abstract}
Abstrak. Kecemasan merupakan hal yang normal terjadi dalam kehidupan manusia. Pada kadar yang rendah, kecemasan dapat membantu seseorang untuk waspada dan bersiap untuk menghadapi bahaya. Namun, jika kadarnya berlebihan kecemasan dapat menimbulkan ketidaknyamanan dan mengganggu kehidupan sehari-hari. Penelitian ini bertujuan untuk melihat gambaran kecemasan yang dialami oleh narapidana sekaligus melihat upaya apa yang telah dilakukan Lembaga Pemasyarakatan Kelas I Semarang untuk menangani kasus kecemasan tersebut. Desain dalam penelitian ini adalah studi kasus, dengan subyek penelitian berjumlah tiga orang narapidana yang melakukan tindak pidana pembunuhan. Alat pengumpul data yang digunakan adalah teknik observasi, wawancara dan dokumentasi. Kemudian penelitian ini memanfaatkan model Miles dan Huberman untuk menganalisis data yang telah didapatkan. Hasil penelitian menunjukkan ketiga subyek penelitian mengalami kecemasan yang termasuk kedalam kategori sedang cenderung berat. Beberapa indikasi kecemasan muncul pada subyek penelitian, yaitu: 1) keringat berlebih, 2) gelisah, gugup dan resah. 3) insomnia dan mimpi buruk, 4) perilaku menghindar, 5) mudah marah dan sedih, 6) merasa terancam dengan seseorang, situasi atau peristiwa yang sebenarnya tidak mengamcam, 7) berpikir tentang hal menggangu yang sama berulang-ulang, dan 8) sulit memusatkan pikiran. Kecemasan yang mereka alami tidak hanya menghambat aktivitas keseharian mereka, tapi juga dapat menurunkan kualitas kesehatan mereka baik secara fisik maupun psikis.
\end{abstract}

Kata kunci: Kecemasan, Narapidana, Pembunuhan

\begin{abstract}
Anxiety was a normal thing that was going on in human life. At low levels, anxiety helped someone to be alert and prepare to face the danger. However, at the high level, anxiety caused discomfort and disturb the life. The aims of this research were to observe the anxiety experienced by prisoners and notice the efforts of The Correctional Institution Class 1 Semarang about what have been done in handling the case of the anxiety. The research design was case study, with three of prisoners as subjects who committed the murder. The observation, interviews and documentation were the data collection techniques. This research used Miles and Huberman as models to analyze the data that has been obtained. The research showed that the subjects' anxiety experienced were medium category tending to beavy. Some anxiety indications appeared on the research's subjects, they were : 1.) sweat excess 2.) restless, nervous, and unsettled 3.) insomnia and nightmare 4.) dodge behavior 5.) irritable and sad easily 6.) felt threatened by someone, in the situation that did not actually threat. 7) thinking about the same annoying repeatedly 8.) difficulty concentration. The anxiety they had were not only inbibiting their activities but also decreased the quality of their health, in physically either psychologically.
\end{abstract}

Keywords: Anxiety, Prisoners, Murder 


\section{PENDAHULUAN}

Kecemasan merupakan istilah yang sangat akrab dalam kehidupan keseharian kita yang menggambarkan keadaan dimana seseorang mengalami kekhawatiran, kegelisahan, ketakutan, dan perasaan tidak tenang. Keadaan tersebut dapat terjadi atau menyertai kondisi situasi kehidupan dan berbagai gangguan kesehatan. Kecemasan diperkirakan menempati 12\% dari seluruh gangguan psikologis di dunia. Prevalensinya di masyarakat diperkirakan 3\%. Di Indonesia prevalensi kecemasan diperkirakan berkisar antara 9\% - 12\% populasi umum. Data Riskesdas tahun 2013, menunjukan bahwa prevalensi nasional (depresi dan kecemasan) pada penduduk berusia di atas 15 tahun mencapai rata-rata secara nasional 6,0\%. Namun sebagian masyarakat di Indonesia cenderung mengabaikan hal tersebut, gangguan kecemasan dianggap normal bukan sesuatu yang harus ditangani (Farmacia, dalam Hidayat, dkk; 2017).

Freud (dalam Safaria dan Saputra, 2009:49) mengatakan kecemasan merupakan reaksi terhadap ancaman dari rasa sakit maupun dunia luar yang tidak siap ditanggulangi dan berfungsi memperingatkan individu akan adanya bahaya. Sedangkan Steven Schwartz, S (dalam Annisa dan Ifdil; 2016) mengatakan kecemasan merupakan keadaan emosional negative yang ditandai dengan adanya firasat dan somatik ketegangan, seperti jantung berdetak kencang, berkeringat, serta kesulitan bernapas. Kecemasan serupa dengan rasa takut tetapi dengan fokus kurang spesifik, sedangkan ketakutan biasanya merespon terhadap beberapa ancaman langsung, sedangkan kecemasan ditandai oleh kekhawatiran tentang bahaya tidak terduga yang akan terjadi di masa depan. Atkinson (1983:212) mengatakan kecemasan dapat muncul karena adanya: 1) Ancaman (Threat), yang disebabkan oleh sesuatu yang benar-benar realistis maupun yang tidak realistis. Contohnya: ancaman terhadap tubuh, jiwa atau psikisnya (misalnya seperti kehilangan kemerdekaan, arti hidup dan ancaman akan kehilangan eksistensinya). 2) Pertentangan (Conflict), hal ini muncul karena adanya dua keinginan yang keadaannya saling bertolak belakang. 3) Ketakutan (Fear), dan 4) Kebutuhan yang tidak terpenuhi (Unneed need). Selama masa hukuman pidana, narapidana mengalami keempat kondisi yang telah disebutkan diatas sehingga dapat menyebabkan narapidana mengalami kecemasan. Namun, sebenarnya terdapat banyak faktor lain yang dapat menyebabkan timbulnya perasaan cemas pada narapidana, Shienkfild (dalam Salim;dkk, 2016) menyebutkan bahwa gangguan cemas yang terjadi pada narapidana dipengaruhi oleh beberapa faktor yaitu usia, lama hukuman, waktu menjelang bebas, dukungan keluarga dan dukungan sosial masyarakat. Selain itu dalam penelitian yang dilakukan oleh Putri, dkk (2014) dijelaskan bahwa tingkat pendidikan dapat memberikan pengaruh terhadap kecemasan yang dialami oleh narapidana, dimana semakin tinggi tingkat pendidikan seseorang maka akan semakin mudah berpikir rasional dan menangkap informasi baru termasuk dalam menguraikan masalah baru, sehingga semakin 
tinggi tingkat pengetahuan narapidana akan mempengaruhi perilaku termasuk dalam menggunakan koping yang konstruktif dalam menyelesaikan masalah maka menurunkan tingkat kecemasan.

Kecemasan sebenarnya dapat membawa manfaat dalam kehidupan seseorang apabila kecemasan tersebut dapat mendorong individu untuk melakukan hal yang lebih baik sebagai antisipasi atas kecemasannya. Mu’arifah (2005) dalam penelitiannya menyatakan bahwa kecemasan dengan tingkatan ringan sering dipandang konstruktif, karena kecemasan dalam tingkatan ini dapat merangsang seseorang untuk memfokuskan perhatian dan meningkatkan efisiensi dalam performanya. Dengan kata lain kecemasan dapat bersifat adaptif bila keadaan yang tidak menyenangkan tersebut dapat memotivasi seseorang untuk mengatur strategi guna menghadapi tantangan kehidupan. Namun, lain halnya jika kadarnya berlebihan. Kecemasan berlebihan justru dapat menimbulkan ketidaknyamanan, mengganggu fungsi kehidupan sehari-hari, menimbulkan distress, atau menghindari situasi sosial yang menimbulkan stress bagi individu tersebut (DSM IV, dalam Asrori; 2015). Pendapat tersebut selaras dengan hasil penelitian yang dilakukan oleh Dadi, dkk (2016) yaitu, jika seseorang merasa cemas hal tersebut merupakan sesuatu yang normal terjadi dan penting untuk adaptasi dan kelangsungan hidup. Namun, jika tingkat kecemasan cenderung tinggi dan berlebihan, kecemasan tersebut dapat melemahkan individu tersebut. Selanjutnya Lutfa dan Maliya (2008) dalam penelitiannya mengemukakan bahwa dampak kecemasan dapat menyebabkan beberapa gangguan, antara lain: a) fisik (fisiologis), antara lain mual, muntah, diare, pusing, nafsu makan menghilang, menurunnya berat badan ekstrim secara, dan merasa lelah yang luar biasa; b) gejala gangguan tingkah laku, antara lain aktivitas psikomotorik bertambah atau berkurang, sikap penolakan, berbicara kasar, sulit tidur, gerakan yang tidak lazim; c) gejala gangguan mental, antara lain konsentrasi berkurang, pikiran meloncat loncat, kehilangan kemampuan persepsi, hilang ingatan, fobia, ilusi dan halusinasi. Dari beberapa pendapat para ahli dapat saya simpulkan bahwa kecemasan dapat memberikan dampak yang positif dan negative bagi individu. Walaupun dapat memberikan dampak positif namun ternyata terdapat banyak sekali dampak negative yang dapat menghambat kehidupan efektif sehari-hari individu.

Saat melakukan pengamatan awal pada narapidana Lembaga Pemasyarakatan Kelas I Semarang, peneliti menemukan terdapat beberapa narapidana yang mengalami kecemasan ditunjukkan dengan munculnya beberapa indikasi kecemasan seperti gangguan mood, sensitive, cepat marah dan mudah sedih. Kemudian mereka juga menunjukkan perilaku menghindar atau menutup diri seperti mengurung diri dikamar dan tidak mau mengikuti kegiatan pembinaan yang diberikan oleh petugas. Peneliti bahkan menemukan kasus dimana terdapat narapidana yang mengalami kesulitan tidur selama bertahun-tahun yang disebabkan oleh halusinasi pendengaran. Fenomena tersebut membuat peneliti merasa tertarik untuk melakukan studi lebih lanjut untuk 
melihat bagaimana gambaran kecemasan yang dialami oleh narapidana di Lembaga Pemasyarakatan Kelas I Semarang. Karena penelitian ini merupakan penelitian studi kasus, peneliti memberikan batasan atau lebih memusatkan perhatian hanya kepada narapidana dengan kasus pembunuhan. Pemusatan perhatian hanya kepada salah satu tindak pidana tersebut dilakukan untuk memudahkan peneliti untuk mendalami kasus secara intensif dan terperinci. Selain ingin memperoleh gambaran terkait kecemasan yang dialami oleh narapidana, peneliti juga tertarik untuk mengkaji lebih lanjut bagaimana layanan yang telah diberikan Lembaga Pemasyarakatan untuk menangangi kecemasan tersebut. Dengan dilakukannya penelitian ini diharapkan mampu memberikan kontribusi dalam menambah pengetahuan terkait kecemasan yang dialami oleh narapidana sehingga petugas Lembaga Pemasyarakatan dapat melakukan pembinaan, bimbingan dan layanan yang tepat sesuai dengan keadaan tersebut.

\section{METODE}

Metode yang digunakan dalam penelitian ini adalah metode penelitian kualitatif. Moleong (2012:6) mendefinisikan penelitian kualitatif merupakan sesuatu penelitian yang memiliki maksud untuk memahami suatu fenomena tentang apa yang dialami oleh subyek penelitian, misalnya perilaku, persepsi, motivasi, tindakan dan lain-lain secara holistik dan dengan cara deskriptif dalam bentuk kata-kata dan bahasa pada suatu konteks khusus yang alamiah dengan memanfaatkan metode alamiah. Sedangkan Sugiyono (2015:9) mengatakan metode penelitian kualitatif adalah metode penelitian yang berlandaskan pada filsafat postpositivisme, digunakan untuk meneliti pada kondisi obyek yang alamiah, (sebagai lawannya adalah eksperimen) dimana peneliti adalah sebagai instrument kunci, teknik pengumpulan data dilakukan secara triangulasi (gabungan), analisis data bersifat induktif/kualitatif, dan hasil penelitian kualitatif lebih menekankan makna daripada generalisasi.

\section{Partisipan}

Partisipan dalam penelitian ini sebanyak tiga orang narapidana yang diperoleh dari hasil rekomendasi Psikolog Lapas dan melalui seleksi wawancara lebih lanjut. Adapun kriteria partisipan dalam penelitian ini, yaitu: 1) Narapidana di Lembaga Pemasyarakatan Kelas I Semarang, 2) Narapidana dengan kasus pembunuhan yang terindikasi mengalami kecemasan, 3) Bersedia menjadi informan.

\section{Desain Penelitian}


Penelitian ini menggunakan desain penelitian studi kasus dimana peneliti bermaksud untuk memperoleh gambaran kecemasan yang dialami oleh narapidana dengan kasus pembunuhan di Lapas Kelas I Semarang. Desain penelitian ini peneliti pilih karena desain ini merupakan strategi yang tepat apabila pokok pertanyaan suatu penelitian berkenaan dengan bagaimana dan mengapa, bila peneliti hanya mempunyai sedikit peluang untuk mengontrol peristiwa yang akan diselidiki, dan bilamana fokus penelitiannya terletak pada fenomena kontemporer (masa kini) di dalam konteks kehidupan nyata (Yin, 2014:1).

Black \& Champion (dalam Herdiansyah, 2015:159-160) mengemukakan kelebihan-kelebihan dari desain penelitian studi kasus adalah: 1) bersifat luwes dalam hal metode pengumpulan data yang digunakan, 2) dapat lebih menjangkau dimensi yang lebih spesifik dari topic yang diselidiki, 3) dapat dilakukan secara lebih praktis pada banyak lingkungan sosial, 4) studi kasus dapat digunakan sebagai penguji dari suatu teori, 5) dapat dilakukan dengan dana yang minim jika dilakukan dengan metode pengumpulan data yang sederhana.

Tohirin (2012:25) menjabarkan langkah-langkah yang terdapat dalam desain penelitian studi kasus, yaitu: 1) melakukan analisis mendalam mengenai kasus dan situasi yang berkenaan dengan fokus yang diteliti, 2) berusaha memahaminya dari sudut pandang orang-orang yang melakukan aktivitas dalam kasus tersebut, 3) mencatat berbagai aspek hubungan komunikasi dan pengalaman, 4) membangkitkan perhatian pada cara factor-faktor tersebut berhubungan satu sama lain.

\section{Instrumen Penelitian dan Teknik Pengumpulan Data}

Pada penelitian kualitatif, yang menjadi instrumen utama adalah peneliti itu sendiri. Moleong (2012:168) menyebutkan peneliti dalam penelitian kualitatif selain sebagai perencana, ia juga sebagai pelaksana pengumpulan data, analisis, penafsiran data dan pada akhirnya peneliti pula yang menjadi pelapor hasil penelitiannya. Dalam hal peneliti sebagai instrumen utama atau instrumen kunci ketika penggalian dan pengumpulan data di lapangan peneliti menggunakan instrumen seperti pedoman observasi, dokumentasi dan wawancara agar data yang diperoleh dalam penelitian ini terarah, mendalam dan menyeluruh.

Dalam penelitian ini peneliti menggunakan teknik wawancara semiterstuktur pada awal penelitian, tujuannya adalah untuk menemukan permasalahan secara lebih terbuka, dimana subyek penelitian atau klien diminta untuk menyampaikan pendapat dan ide-idenya. Kemudian setelah terkumpulnya data-data awal, peneliti melakukan wawancara lebih lanjut dengan teknik wawancara terstruktur, dimana pada teknik ini peneliti telah menyiapkan pertanyaan-pertanyaan tertulis. Dengan wawancara tertulis ini nantinya setiap subyek penelitian akan diberi pertanyaan serupa lalu 
peneliti mencatatnya. Wawancara yang dilakukan secara terstruktur ini berpedoman pada kerangka kerja RESPECTFUL.

\section{Teknik Analisis Data}

Analisis data selama dilapangan peneliti menggunakan Model Miles dan Huberman. Langkahlangkah dalam analisis data kualitatif adalah:

1. Data Collection (pengumpulan data). Peneliti melakukan proses pengumpulan data sebanyakbanyaknya dari berbagai informan melalui observasi, wawancara dan dokumentasi. Data yang terkumpul akan ditelaah dan dipilah sehingga akan dihasilkan data yang sesuai dan akan dianalisis sebagai laporan penelitian sedangkan data yang tidak sesuai akan direduksi.

2. Data Reduction (reduksi data). Mereduksi data berarti merangkum, memilih hal-hal yang pokok, memfokuskan pada hal-hal yang penting, dicari tema dan polanya.

3. Data Display (penyajian data). Dalam penyajian data ini bisa dilakukan dalam bentuk uraian singkat, dan tabel. Yang paling sering digunakan untuk menyajikan data dalam penelitian kualitatif adalah dengan teks yang bersifat naratif.

4. Conclusion drawing/ verivication (penarikan kesimpulan dan verivikasi). Kesimpulan awal yang dikemukakan masih bersifat sementara, dan akan berubah bila tidak ditemukan bukti-bukti yang kuat dan mendukung pada tahap pengumpulan data berikutnya. Tetapi apabila kesimpulan yang dikemukakan pada tahap awal, didukung oleh bukti-bukti yang valid dan konsisten saat peneliti kembali ke lapangan mengumpulkan data, maka kesimpulan yang dikemukakan merupakan kesimpulan yang kredibel. (Sugiyono, 2015:247)

\section{Pemeriksaan Keabsahan Data}

Moleong (2012:324) menyatakan kredibilitas berfungsi untuk menunjukkan tingkat kepercayaan atas hasil temuan penelitian. Kredibilitas dapat menggunakan teknik perpanjangan keikut-sertaan, ketekunan pengamatan, triangulasi, pengecheckan sejawat, kecakupan referensial, kajian kasus negative dan pengecekan anggota (membercheck). Uji keabsahan data dalam penelitian ini menggunakan triangulasi yaitu pengecekan data dari berbagai sumber dengan berbagai cara, dan berbagai waktu. Data akan dikatakan kredibel apabila ada konsistensi antara sumber dengan data yang telah dikumpulkan tadi. Akan tetapi jika menghasilkan data yang berbeda-beda sementara sumber atau teknik nya sama, maka peneliti melakukan diskusi lebih lanjut kepada sumber data yang bersangkutan atau yang lain untuk memastikan data mana yang dianggap benar. Selain menggunakan triangulasi untuk memeriksa keabsahan data, peneliti juga melakukan membercheck guna mengecek apakah data yang peneliti peroleh sesuai dengan apa yang diberikan pemberi data. 


\section{TEMUAN}

\section{Subyek FE}

FE berusia 24 tahun kala dia melakukan tindak pidananya. Setelah melalui proses persidangan yang panjang akhirnya ia dijatuhi vonis hukuman penjara seumur hidup. FE mengaku tidak dengan sengaja melakukan pembunuhan karena ia hanya berniat mendatangi orang yang telah memukuli adik bungsunya. Namun, demi keselamatan dirinya ia membawa pisau lipat dari rumah untuk membela diri jika saja terjadi perkelahian. FE membutuhkan waktu yang cukup lama untuk beradaptasi dengan kehidupan dan status barunya. Namun, setelah 8 tahun berlalu ia mengaku sekarang merasa cukup stabil, tetapi terkadang ia masih merasa was-was. Ia merasa cemas dan khawatir masa hukumannya akan terlalu lama karena ia harus menunggu grasi dari Presiden untuk dibebaskan dan ia tidak tahu kapan grasi tersebut akan diberikan. Ia juga merasa kasihan dengan keluarganya kalau ia terlalu lama di penjara. Ia merasa cemas tentang ekonomi keluarganya, karena sejak ia dipenjara aset-aset bisnisnya dijual satu per satu demi menafkahi keluarganya. Pada peneliti FE mengatakan bahwa sekarang ia bergantung pada uang yang diberikan oleh orangtuanya. FE mengaku merasa penuh ketidakpastian akibat aturan hukum yang terus berubah-ubah membuatnya semakin lama mendapatkan grasi dari presiden sehingga akan memperpanjang masa hukumannya. Selain merasakan kecemasan FE juga masih memendam perasaan bersalah, ia mengaku kerap mengalami mimpi buruk mengenai kejadian perkelahian kala itu yang menyebabkan ia masuk penjara.

Peneliti juga mengamati bahwa telah muncul beberapa indikasi kecemasan pada FE yaitu: 1) gelisah dan resah, 2) khawatir akan sesuatu, 3) berpikir tentang hal menggangu yang sama berulangulang, 4) mengalami mimpi buruk. Kemudian untuk memastikan lebih lanjut pada tingkatan mana kecemasan yang dialami oleh FE peneliti memberikan skala "Seberapa Cemaskah Anda?" kepada FE. Setelah skor jawaban dari FE didapatkan, skor skala tersebut menunjukkan hasil 76 dari 100 dan 75 dari 135, sehingga peneliti dapat menarik kesimpulan bahwa FE mengalami kecemasan dengan tingkatan kecemasan sedang karena skor FE melebihi separuh dari keseluruhan skor total.

Kecemasan yang dialami oleh FE sedikit banyak berdampak pada kehidupan keseharian FE. Hukuman seumur hidup yang harus dijalaninya membuatnya khawatir, merasa harap-harap cemas. Perasaan cemas dan khawatir tersebut membuatnya menjadi pribadi yang kurang stabil, suasana hati yang cenderung berubah-ubah, lebih banyak menyendiri dan menutup diri, hal serupa pun juga dikatakan oleh Ibu Ari selaku Psikolog di Lapas.

\section{Subyek $A B S$}


ABS merupakan lulusan STM Penerbangan. Ia sempat bekerja sebagai mekanik pesawat, tetapi setelah menjalani kurang lebih dua tahun ia diberhentikan karena karena kurang disiplin. Selain menjadi mekanik pesawat ABS juga pernah bekerja di pabrik plastic dan pabrik kertas. Diketahui saat ditangkap ABS baru berusia 22 tahun. Ia ditangkap karena membunuh pacarnya yang berinisial F. Ketika ditanyai mengapa ia membunuh pacarnya, ia mengaku membunuh karena disuruh oleh pacarnya yang lain yang berinisial L. ABS mengaku takut, takut dibayangi arwah sang pacar yang ia bunuh dan ia pun takut ditangkap polisi. Ia merasa bingung, tidak tenang dan sangat cemas sehingga ia melarikan diri ke beberapa kota. Ketika di tangkap pada tahun 2012 ia mulai mendengarkan suara-suara aneh yang menghantuinya namun hanya sesekali. Pada tahun 2014 ia mulai intens mendengarkan suara-suara yang menganggunya setiap malam sehingga ABS tidak dapat tidur. Hal tersebut hingga membuatnya harus mengkonsumsi obat-obatan supaya dapat tidur. Selain tak dapat tidur ABS pun mengaku kerap menghabiskan waktunya untuk melamun.

ABS dijatuhi hukuman penjara yang cukup lama yaitu 20 tahun. Kemudian ketika ditanyai lebih lanjut apakah ia merasa cemas menghadapi kehidupan di luar Lapas, ia mengatakan ia takut. ABS mengaku ia sangat takut dikucilkan oleh tetangganya sehingga ia berencana untuk bersembunyi di rumah dalam kurun waktu yang cukup lama yaitu 1 tahun baru setelah itu ia akan mencari pekerjaan. Hal tersebut juga teramati oleh Ibu Ari, beliau mengatakan bahwa ia melihat ABS merasakan kekhawatiran dalam menghadapi dunia di luar Lapas ketika ia akan bebas, ia belum siap secara mental dan belum sanggup untuk berhadapan dengan masyarakat yang akan mempertanyakan statusnya nanti.

Peneliti juga mengamati bahwa telah muncul beberapa indikasi kecemasan pada ABS, diantaranya: 1) Sulit tidur, 2) mengalami mimpi buruk, 3) merasa gelisah, gugup dan resah, 4) merasa terancam dengan kehadiran seseorang dan situasi atau peristiwa yang sebenarnya tidak mengancam, 5) berpikir atau melamunkan tentang hal mengganggu yang sama berulang-ulang, 6) sulit konsentrasi dan memusatkan pikiran. Dengan munculnya indikasi-indikasi tersebut membuat peneliti dapat menarik kesimpulan bahwa ABS mengalami kecemasan. Kemudian untuk memastikan lebih lanjut pada tingkatan mana kecemasan yang dialami oleh ABS peneliti juga memberikan skala "Seberapa Cemaskah Anda?" kepada ABS dan hasilnya pun 54 dari 100 dan 84 dari 135, sehingga dapat peneliti tarik kesimpulan bahwa ABS mengalami kecemasan dengan tingkatan sedang hingga berat karena skor ABS melebihi separuh dari keseluruhan skor total.

ABS mengaku kerap mengalami mimpi buruk. Ia bahkan sampai mengalami halusinasi suara dimana menurut penuturannya ia kerap mendengar suara-suara yang seakan-akan menyalahkannya. Halusinasi suara tersebut ia alami sejak tahun 2014 dan bertambah parah setiap harinya sehingga menyebabkan ABS tidak dapat tidur sama sekali dan harus menjalani perawatan di poliklinik. Mimpi 
buruk, gangguan tidur dan halusinasi suara yang dialami ABS akibat kecemasan yang dialaminya tentu sangatlah mengganggu kehidupan kesehariannya. Ia bahkan sampai dikeluarkan dari Bingker karena kerap tidak masuk. Ketika ditanyai alasannya ABS mengaku ia tidak masuk karena ia hanya dapat tidur pada siang hari, akibat gangguan tidur dan halusinasi suara yang dirasakannya.

\section{Subyek DCP}

DCP merupakan salah satu narapidana yang saat ini usianya masih 17 tahun. Di usianya saat ini DCP telah menginjak tahap perkembangan remaja akhir. Bulantika, dkk (2018) mengatakan bahwa kecemasan rentan terjadi pada periode remaja karena periode ini termasuk fase transisi dan sering disebut periode badai karena adanya ketidakstabilan emosional yang lebih lanjut dapat menyebabkan banyak masalah. DCP hanyalah lulusan Sekolah Dasar. Sebenarnya ia sempat bersekolah hingga kelas 3 SMP, tetapi ia dikeluarkan dari sekolah karena tawuran. Setelah itu ia tidak melanjutkan sekolah dan kegiatannya adalah mengantarkan barang-barang dari warung milik orangtuanya, seperti aqua dan sebagainya. Selain itu DCP mengaku setiap sore kerap mengikuti balap liar di BSB dan malam harinya terkadang ia mabuk-mabukan bersama teman-temannya.

Peneliti menemukan perbedaan cerita dari penuturan DCP terkait kronologi pembunuhan yang ia lakukan dan dengan apa yang tertulis di Berita Acara Penangkapan. Saat wawancara DCP mengatakan bahwa ia tidak sadar membunuh dikarenakan mabuk. Sepulang mabuk-mabukan di rumah temannya, ia bertemu wanita muda yang usianya sekitar 23 tahun. DCP mencekik wanita tesebut hingga tewas. Berdasarkan hal tersebut peneliti dapat menyimpulkan bahwa DCP menutupi sebuah fakta dan merupakan pribadi yang kurang jujur sehingga peneliti mencoba mengkonfirmasi kembali kebenaran cerita kepada DCP dan barulah DCP menceritakan runtutan kronologi pembunuhannya tanpa ada yang ia sembunyikan dan manipulasi ceritanya. Bersamaan dengan peneliti mengkonfirmasi kebenaran cerita tersebut, peneliti juga menemukan sebuah fakta baru bahwa DCP merupakan pecandu narkoba sejak lama, yakni sejak ia masih duduk di kelas 1 SMP. Ia mengaku memakai narkoba karena dipengaruhi oleh teman dekatnya dan ia merasa penasaran. Pada saat melakukan pembunuhan DCP mengaku pula bahwa ia sedang dalam pengaruh alkohol dan narkoba. Saat ini DCP sedang diisolasi di blok hunian K, karena ia terciduk oleh petugas memiliki pipet (alat untuk mengkonsumsi narkoba) walaupun ia mengaku pipet tersebut milik temannya dan ia hanya dijebak.

Kemudian DCP menuturkan bahwa rasa menyesal dialami DCP setelah sadar bahwa ia telah membunuh seseorang. Ia mengatakan ketika terbangun dari tidurnya ia langsung teringat akan kejadian tersebut. Ia merasa menyesal dan bersalah. Kemudian DCP mengaku ia sempat mengalami mimpi didatangi dan diajak bicara oleh wanita yang dicekiknya hingga tewas. Ia mengaku takut 
digentayangi dan merasa cemas sedikit. Kemudian, selain cemas karena takut dihantui oleh arwah korban yang ia bunuh DCP juga merasa cemas dan takut dengan narapidana yang lain, karena ini adalah kali pertamanya ia di penjara.

Peneliti juga mengamati bahwa telah muncul beberapa indikasi kecemasan pada DCP, antara lain: 1) mimpi buruk, 2) perilaku menghindar, 3) gelisah, gugup dan resah, 4) hilang motivasi dan minat untuk melakukan kegiatan, 5) merasa terancam dengan seseorang dan situasi atau peristiwa yang sebenarnya tidak mengancam, 6) berpikir tentang hal menggangu yang sama berulang-ulang, 7) sulit konsentrasi dan memusatkan pikiran. Kemudian untuk memastikan lebih lanjut pada tingkatan mana kecemasan yang dialami oleh DCP peneliti menggunakan Skala 'Seberapa Cemaskah Anda?”. Hasil skor skala tersebut menunjukkan angka 53 dari 100 dan 81 dari 100 sehingga dapat dikatakan bahwa DCP mengalami kecemasan dengan tingkatan sedang hingga berat karena skor DCP melebihi separuh dari keseluruhan skor total.

Kecemasan yang DCP alami sedikit banyak memberikan pengaruh terhadap kehidupan kesehariannya. Walaupun DCP merupakan seseorang dengan kepribadian ekstrovert namun DCP menunjukkan kecenderungan untuk menghindar dari kegiatan-kegiatan pembinaan. Hal tersebut peneliti temukan pada saat melakukan pengamatan DCP tidak mengikuti senam pagi dan LKBB sesuai waktu yang telah dijadwalkan. DCP pun bercerita bahwa ia pernah bekerja di Bingker namun ia di keluarkan karena jarang masuk. Kemudian saat wawancara berlangsung pun peneliti melihat raut kegelisahan dan gerak-gerik yang tampak gugup pada diri DCP seakan-akan ia sedang dalam situasi yang terancam. kemudian DCP juga terlihat sulit memusatkan konsentrasinya, saat peneliti memberikan pertanyaan, DCP kurang cepat memahaminya dan terkadang tidak dapat menjawab pertanyaan tersebut. Hal tersebut tentu saja mengganggu kefektifan aktivitas kesehariannya.

\section{PEMBAHASAN}

\section{Latar Belakang Personal Narapidana}

Berdasarkan hasil wawancara berbasis kerangka kerja RESPECTFUL yang peneliti lakukan kepada ketiga subyek penelitian ditemukan beberapa kesamaan dalam beberapa aspek latar belakang personal mereka. Kesamaan pertama ditemukan dalam aspek religion atau kerohanian. Semua subyek penelitian beragama islam dan merupakan muslim sejak lahir namun mereka kerap lalai dengan sengaja meninggalkan ibadah sholat wajib dan juga mereka tidak melaksanakan ibadah puasa selama sebulan penuh. Sehingga dengan ditemukannya fakta tersebut peneliti dapat menarik 
sebuah simpulan bahwa tingkat religiusitas ketiga subyek penelitian cenderung rendah. Kesamaan yang kedua ditemukan dalam aspek kelas ekonomi. Ketiga subyek penelitian berasal dari latar belakang kelas ekonomi menengah cenderung kebawah. Kesamaan latar bekalang kelas ekonomi ini juga berpengaruh pada kemiripan tempat tinggal dari ketiga subyek penelitian yaitu sama-sama di tengah perkampungan. Kesamaan selanjutnya ditemukan pada identitas gender dan orientasi seksual subyek penelitian. Ketiganya menunjukkan kecenderungan maskulinitas dan mereka semua menyukai lawan jenis yaitu wanita. Kemudian kesemua subyek penelitian sama-sama memiliki pengalaman di masa lalu yang menyisakan trauma hingga kehidupan mereka saat ini. Trauma tersebut juga menjadi salah satu pemicu perilaku agresif seperti memukul, berkelahi dan bahkan membunuh.

Walaupun memiliki beberapa kesamaan, tetapi setiap narapidana tetaplah individu yang unik dan memiliki ciri khasnya masing-masing. Misal, karena usia setiap subyek penelitian berbeda-beda, mereka memiliki tingkat kematangan psikologis yang berbeda-beda. Perbedaan kematangan psikologis inilah yang mempengaruhi cara mereka bersikap dan bagaimana cara mereka untuk mengatasi kecemasan yang mereka alami. Kemudian setiap subyek penelitian walaupun berasal dari kelas ekonomi yang sama dan lingkungan tempat tinggal yang mirip, mereka mempunyai latar belakang tipe keluarga yang berbeda-beda. Perbedaan tipe keluarga tentu saja menjadikan pola asuh dalam keluarga setiap subyek penelitian berbeda pula. Perbedaan inilah yang dapat membuat pola berpikir, berperilaku, dan cara subyek penelitian menyikapi sesuatu berbeda pula.

\section{Jenis Kecemasan}

Freud (dalam Suryabrata, 1993:139) menjelaskan bahwa terdapat tiga macam kecemasan, yaitu: a) kecemasan realistis, b) kecemasan neurotis, dan c) kecemasan moral. Sedangkan Nevid dan Greene (2005) membagi kecemasan menjadi lima jenis, yaitu: a) gangguan panic, b) gangguan cemas menyeluruh, c) gangguan obsesif kompulsif, d) gangguan fobia, dan e) Gangguan stress akut dan stress pasca trauma.

Berdasarkan hasil pengamatan yang peneliti dapatkan ketika wawancara, peneliti menemukan bahwa ketiga narapidana mengalami jenis kecemasan yang serupa yaitu kecemasan moral dan gangguan stress pasca trauma. Kecemasan moral merupakan kecemasan yang disebabkan karena dimasa lampau seseorang telah mendapat hukuman sebagai akibat dari perbuatan yang melanggar kode moral dan mungkin akan mendapat hukuman lagi. Selain mengalami kecemasan moral, ketiga narapidana juga mengalami gangguan stress pasca trauma. 
Gangguan stress pasca trauma atau post traumatic stress disorder (PTSD) adalah reaksi maladaptive berkelanjutan terhadap suatu pengalaman traumatis yang dialami seseorang lebih dari kurun waktu satu bulan. Peristiwa pembunuhan yang mereka lakukan juga merupakan peristiwa traumatis yang membuat mereka dihantui oleh rasa bersalah. Mereka merasa bersalah dibuktikan dengan gangguan tidur dan mimpi buruk yang ketiganya alami, walaupun intensitasnya berbedabeda. Bahkan salah satu subyek penelitian yaitu ABS mengalami halusinasi suara. Suara yang ia dengarkan merupakan suara-suara yang selalu menyalahkannya. Suara-suara tersebut kerap terdengar mulai tahun 2014 hingga sekarang dan selalu muncul setiap malam sehingga menyebabkan ia tidak dapat tidur. Bahkan ABS sudah menjadi pasien poliklinik di Lembaga Pemasyarakatan dan mengkonsumsi sejumlah obat yang menurut ABS dapat membuatnya tidur. Ibu Ari psikolog yang berada di Lembaga Pemasyarakatan mengatakan bahwa ketiga narapidana alami trauma dan merasakan perasaan bersalah yang begitu tinggi sehingga terjadilah kecemasan yang mengganggu efektivitas kehidupan sehari-hari narapidana. "Faktor setelah dia mendapatkan bukuman tinggi.. apalagi faktor pembunuhan.. biasanya orang yang melakukan tindak. pembunuban pasti setelah akbirnya ketabuan bahwa dia membunuh pasti akan guilty feelingnya tinggi dan ketika perasaan bersalahnya berlebihan depresi merasa stress depresi kann gituu gangguan tidur, susah makan, gangguan perilaku pasti akan muncul."

\section{Tingkatan Kecemasan}

Stuart (2007) membagi tingkat kecemasan menjadi empat tingkatan, yaitu: 1) kecemasan ringan, 2) kecemasan sedang, 3) kecemasan berat dan 4) panik. Berdasarkan hasil skala kecemasan dan studi literature dari pendapat para ahli, peneliti menyimpulkan bahwa ketiga narapidana mengalami kecemasan dengan tingkatan sedang.hingga berat. Seseorang yang mengalami kecemasan dengan tingkatan sedang menurut Stuart (2007) biasanya ditandai dengan merasa gelisah, berpikiran sempit, kurang fokus, sulit tidur dan merasakan perasaan yang tidak enak. Sedangkan bila seseorang mengalami kecemasan tinggi ketegangan dan kegelisahan yang dirasakannya akan semakin meningkat pula, ia menjadi berpikiran lebih sempit, tidak mampu menyelesaikan masalah yang dialaminya dan perasaan terancam akan meningkat

\section{Faktor Penyebab Kecemasan}

Kecemasan merupakan segala bentuk situasi yang mengancam kesejahteraan organisme (Atkinson, 1983:212). Kecemasan dapat muncul karena adanya: 1) Ancaman (Threat), 2) Pertentangan (Conflict), 3) Ketakutan (Fear), 4) Kebutuhan yang tidak terpenuhi (Unneed need). 
Menurut pengamatan peneliti, narapidana mengalami keempat kondisi yang telah dijelaskan diatas. Narapidana merasa terancam karena ia kehilangan kemerdekaan dan kebebasannya sebagai bentuk hukuman atas tindakan pembunuhan yang telah mereka lakukan. Hal tersebut juga menimbulkan pertentangan, karena kenyataan mereka harus dihukum dan hilang kebebasannya bertolak belakang dengan keinginan semua orang yaitu bebas dan merdeka. Kemudian, hilangnya kebebasan dan kemerdekaan itu menyebabkan tidak terpenuhinya kebutuhan-kebutuhan yang seharusnya terpenuhi, misal rasa aman, rasa dicintai, dekat dengan orang-orang yang dicintai, kebutuhan akan seks, dan lain sebagainya. Setelah sekian lama dipenjara, narapidana merasakan cemas dan takut akan penolakan ketika mereka kembali ke tengah-tengah masyarakat, mereka takut akan dikucilkan akibat stigma negative yang ada di masyarakat terkait narapidana apalagi mereka adalah terpidana dengan kasus pembunuhan.

Kemudian menurut Corey (2009) faktor-faktor penyebab kecemasan dapat digolongkan menjadi:

1) Faktor Kognitif, menyatakan bahwa kecemasan dapat timbul sebagai akibat dari antisipasi harapan akan situasi yang menakutkan dan pernah menimbulkan situasi yang menimbulkan rasa sakit, maka apabila individu dihadapkan pada peristiwa yang sama individu akan merasakan kecemasan sebagai reaksi atas adanya bahaya.

2) Faktor Lingkungan, salah satu penyebab munculnya kecemasan adalah dari hubunganhubungan dan ditentukan langsung oleh kondisi-kondisi, adat-istiadat, dan nilai-nilai dalam masyarakat.

3) Faktor Proses Belajar, kecemasan timbul sebagai akibat dari proses belajar. Manusia mempelajari respon terhadap stimulus yang memperingatkan adanya peristiwa berbahaya dan menyakitkan yang akan segera terjadi.

Berdasarkan teori yang dijelaskan oleh Corey diatas peneliti menemukan bahwa ketiga narapidana mengalami kecemasan yang disebabkan oleh faktor kognitif dimana narapidana merasakan cemas akibat pikiran-pikiran irasional mengenai nasibnya dimasa yang akan datang, misal peraturan terkait pembebasan yang kerap berubah-ubah membuat narapidana menjadi waswas dan memiliki pikiran negative yang berlebih sehingga menimbulkan reaksi cemas. Kemudian keadaan lingkungan yang berubah drastis antara lingkungan tempat tinggal dan lingkungan di Lapas yang tentunya sangat berbeda membuatnya merasa khawatir dan memerlukan upaya lebih untuk beradaptasi. Selain itu, ketika menjelang bebas narapidana juga harus belajar beradaptasi kembali dengan kehidupan di luar Lapas, hal ini tentu membuat narapidana cemas.

Selanjutnya Spielberger (dalam Oktaviany dan Halim, 2014) menjelaskan bahwa secara umum kecemasan dapat disebabkan oleh dua faktor, yaitu: 1) Faktor proximal, merupakan kondisi 
langsung yang dapat menimbulkan kecemasan, seperti situasi yang sedang dihadapi saat itu dan faktor kepribadian. 2) Faktor distal, merupakan faktor di luar lingkungan individu yang secara tidak langsung dapat menimbulkan kecemasan, seperti status kondisi ekonomi, status ras minoritas, dan pengalaman di masa lalu. Berdasarkan teori tersebut peneliti menemukan bahwa ketiga narapidana mengalami kecemasan yang disebabkan oleh faktor proximal maupun faktor distal. Mereka mengalami kekhawatiran akan pandangan masyarakat terhadap seorang mantan narapidana, penerimaan lingkungan, cemas dalam menghadapi kehidupan yang belum jelas, situasi baru yang mungkin menolak mereka, mobilisasi ekonomi, dan lain sebagainya.

\section{Dampak Kecemasan}

Kecemasan yang berada di tingkatan yang cenderung ringan, dapat membantu seseorang untuk waspada, termotivasi untuk melakukan sesuatu dan bersiap untuk menghadapi situasi 'bahaya' atau meminimalisir dampak bahaya tersebut. Misal, kecemasan akan tidak diberikannya remisi cuti bersyarat kepada narapidana yang terkena pendisiplinan akan memotivasi narapidana tersebut untuk berkelakuan baik dan mengikuti kegiatan pembinaan agar mendapatkan remisi Namun, pada tingkatan yang cenderung tinggi, cemas dapat menyebabkan simtom-simtom fisik seperti peningkatan detak jantung, penengangan otot tubuh sehingga timbul reaksi panik (Asmadi, 2008). Dengan timbulnya simtom-simtom fisik tersebut tentunya akan sangat mengganggu efektivitas keseharian individu.

Saat melakukan wawancara peneliti menemukan bahwa narapidana yang menjadi subyek penelitian peneliti mengalami beberapa gangguan yang merupakan dampak dari kecemasan yang mereka alami. Gangguan tersebut berupa perasaan gelisah, gugup, resah dan khawatir. Kemudian mereka pun menjadi lebih sensitive, mudah marah dan tersinggung. Mereka juga sulit fokus dan berkonsentrasi. Selain itu gangguan yang sangat mengganggu keseharian mereka adalah gangguan tidur dan mimpi buruk yang kerap mereka alami terkait tindakan pembunuhan yang mereka lakukan. Bahkan salah satu dari ketiga subyek penelitian, yaitu ABS, mengalami halusinasi suara yang menghantuinya setiap malam selama kurang lebih lima tahun terakhir sehingga ABS harus menjadi pasien poliklinik dan mengkonsumsi sejumlah obat untuk membantunya tidur. Gangguan tidur tersebut tidak hanya berdampak pada kesehatan mereka yang pastinya semakin menurun, tetapi juga berdampak pada kegiatan keseharian mereka yang terhambat. Misal, ABS dan DCP dikeluarkan dari Bingker akibat kurang disiplin dan jarang masuk, karena pada siang hari saat mereka seharusnya masuk dan kerja di Bingker, tetapi mereka harus tidur karena mereka tidak dapat tidur pada malam harinya. 


\section{Gambaran Layanan yang Telah Diberikan Lembaga Pemasyarakatan untuk Menangani Kecemasan Narapidana}

Lembaga Pemasyarakatan Kelas I Semarang telah berupaya memberikan layanan yang dapat menangani kecemasan yang dialami oleh narapidana. Layanan tersebut dilakukan dengan secara indivual maupun secara berkelompok. Layanan tersebut diaplikasikan melalui sosialisasi rutin di tiap blok, motivation training bekerjasama dengan mahasiswa Psikologi atau Bimbingan dan Konseling yang sedang melaksanakan Praktik Kerja Lapangan, kegiatan siraman rohani dan ruqyah rutin tiap minggu diperuntukkan untuk narapidana muslim. Namun menurut pengamatan peneliti, upaya-upaya tersebut belum terlaksana secara maksimal dan efektif. Hambatan dalam proses pemberian layanan tersebut terjadi karena kurangnya petugas dengan latar belakang psikologi atau konseling. Hanya terdapat satu orang Psikolog, sedangkan Lembaga Pemasyarakatan Kelas I Semarang memiliki sekitar 1800an narapidana dan tahanan yang kesemuanya memiliki masalah dan perlu mendapatkan layanan konseling. Belum lagi Ibu Ari, Psikolog di Lapas, juga menjabat sebagai Kepala Seksi Bimbingan Kemasyarakatan yang juga memiliki tugas dan kesibukan lain sesuai dengan jabatannya. Hal tersebut menyebabkan kegiatan-kegiatan seperti sosialisasi dan layanan konseling individual tidak dapat terlaksana secara berkala. Selain itu kegiatan motivation training juga hanya diadakan jika terdapat mahasiswa Psikologi dan Bimbingan dan Konseling yang melaksanakan Praktik Lapangan, selain waktu tersebut kegiatan motivation training tidak dilaksanakan. Padahal menurut peneliti kegiatan tersebut cukup efektif jika diberikan secara rutin kepada narapidana yang mengalami kecemasan, sehingga mereka mendapatkan motivasi, kiat dan trik untuk meningkatkan keterampilan mereka mengelola stress dan cemas ketika berada di dalam Lapas.Kemudian pihak Lapas juga kerap mengadakan kegiatan pengajian, siraman rohani dan ruqyah. Kegiatan tersebut juga baik bagi narapidana yang mengalami kecemasan karena dapat meningkatkan kecerdasan spiritual, yang mana kecerdasan tersebut dapat membantu narapidana meregulasi kecemasan. Namun, kelemahannya kegiatan tersebut hanya dapat diikuti oleh narapidana yang beragama muslim saja, sedangkan di Lembaga Pemasyarakatan Kelas I Semarang juga terdapat narapidana yang menganut kepercayaan lain seperti Katholik, Kristen, Buddha, dan Hindu.

\section{PENUTUP}

Subyek penelitian mengalami kecemasan dengan jenis kecemasan moral. Selain itu mereka juga mengalami gangguan stress pasca trauma (PTSD). Ketiga subyek penelitian mengalami kecemasan dengan tingkatan sedang hingga tinggi. Kecemasan yang dialami oleh subyek penelitian membawakan beberapa dampak yang mengganggu efektivitas kehidupan keseharian mereka. 
Gangguan tersebut berupa perasaan gelisah, gugup, resah dan khawatir. Kemudian mereka pun menjadi lebih sensitive, mudah marah dan tersinggung. Mereka juga sulit fokus dan berkonsentrasi. Selain itu gangguan yang sangat mengganggu keseharian mereka adalah gangguan tidur dan mimpi buruk yang kerap mereka alami terkait tindakan pembunuhan yang mereka lakukan. Lembaga Pemasyarakatan Kelas I Semarang memang telah melakukan beberapa upaya yang dapat mengurangi kecemasan yang dialami oleh narapidananya. Namun upaya-upaya tersebut belum terlaksana secara maksimal dan efektif.

Terdapat keterbatasan dalam penelitian ini, seperti waktu pengambilan data yang terbatas karena saat penelitian peneliti harus selalu diawasi oleh petugas, sedangkan petugas juga memiliki kegiatan lain yang padat sehingga peneliti harus membuat jadwal terlebih dahulu dengan petugas. Selain itu peneliti tidak diperbolehkan membawa telepon genggam maupun alat perekam masuk ke dalam Lapas, sehingga peneliti kesulitan saat mendokumentasikan baik berupa foto maupun rekaman audio. Keterbatasan keikutsertaan peneliti dalam kegiatan sehari-hari narapidana saat berada di dalam blok hunian, karena area tersebut adalah area terlarang yang tidak boleh dimasuki oleh sembarang orang.

Disarankan kepada konselor ataupun psikolog Lembaga Pemasyarakatan Kelas I Semarang, melakukan identifikasi berkala terkait kecemasan yang dialami oleh narapidana dan melakukan layanan konseling yang sesuai dan efektif guna menurunkan tingkat kecemasan dan meminimalisir dampak dari kecemasan tersebut. Kemudian bagi peneliti selanjutnya, mencari strategi maupun cara untuk meminimalisir hambatan yang peneliti temui selama penelitian.

\section{REFERENSI}

Annisa, Dona Fitri dan Ifdil. 2016. Konsep Kecemasan (Anxiety) pada Lanjut Usia (Lansia). KONSELOR. Vol 5(2), 1-7.

Asmadi. 2008. Konsep Dasar Keperawatan. Jakarta EGC.

Asrori, Adib. 2015. Terapi Kognitif Perilaku Untuk Mengatasi Gangguan Kecemasan Sosial. JURNAL ILMLAH PSKOLOGI TERAPAN. Vol 3(1), 89-107.

Atkinson, et al. 1983. Pengantar Psikologi Edisi Kedelapan. Jakarta: Erlangga.

Corey, Gerald. 2009. Teori dan Praktik Konseling dan Psikoterapi. Bandung: Refika Aditama.

Dadi, Abel Fekadu, dkk. 2016. Anxiety and Associated Factors Among Prisoners in North West of Amraha Regional State, Ethiopia. BIOMED CENTRAL PSYCHIATRY. Vol 16(83), 1-6.

Hidayat, Eyet; dkk. 2017. Pengaruh Terapi Relaksasi Progresif Terhadap Penurunan Tingkat Kecemasan dalam Menghadapi Uji Kompetensi Mahasiswa Tingkat III AKPER Muhammadiyah Cirebon. JURNAL KEPERAW ATAN SOEDIRMAN (THE SOEDIRMAN JOURNAL OF NURSING). Vol 12(2), 93-101.

Herdiansyah, Haris. 2015. Metodologi Penelitian Kualitatif untuk Ilmu Psikologi. Jakarta: Salemba Humanika. 
Lutfa, Umi dan Maliya, Arina. 2008. Faktor-Faktor yang Mempengaruhi Kecemasan Pasien dalam Tindakan Kemoterapi di Rumah Sakit Dr, Moewardi Surakarta. BERITA ILMU KEPERAWATAN. Vol 1(4), 187=192.

Moleong, Lexy J. 2012. Metodologi Penelitian Kualitatif. Bandung: PT Remaja. Rosdakarya.

Nevid, J.S, Rathus., dan Greene, B. 2005. Psikolgi Abnormal. Jakarta: Erlangga.

Oktaviany, Ariny dan Halim, Magdalena S. 2014. Pendekatan Expressive Writing pada Narapidana Wanita yang Mengalami Kecemasan Menjelang Masa Bebas. JURNAL ILMLAH PSIKOLOGI MANASA. Vol 3(2), 59-71.

Panthee, Bimala dan Kritpracha, Charuwan. 2011. Review: Anxiety and Quality of life in Patients with Myocardial Infarction. NURSE MEDIA JOURNAL OF NURSING. Vol 1(1), 105-115.

Putri, Dewi Eka, dkk. 2014. Hubungan Dukungan Sosial dengan Tingkat Kecemasan Narapidana di Lembaga Pemasyarakatan Klas II A Muaro Padang Tahun 2014. Ners Jurnal Keperawatan. Vol 10(1), 118-135.

Safaria, Triantoro dan Saputra, Nofrans Eka. 2009. Manajemen Emosi: Sebuah Panduan Cerdas Bagaimana Mengelola Emosi Positif dalam Hidup Anda. Jakarta: Bumi Aksara.

Salim, Shalha Ubaid, dkk. 2016. Gambaran Faktor yang Mempengaruhi Kecemasan WBP Menjelang Bebas Di LP Wanita Kelas II A Bandung. Jurnal Ilmu Keperawatan. Vol. IV(1), 32-42.

Sharma, Neelu, dkk. 2015. A Study of Mental Health Problems in Criminals in Terms of Depression, Anxiety and Stress. GLOBAL JOURNAL OF HUMAN-SOCLAL SCIENCE: A ARTS\&HUMANITIES-PSYCHOLOGY. Vol 15(9), 16-22.

Stuart, G.W. 2007. Buku Ajar Keperawatan Jiwa Edisi 5. Jakarta: EGC

Sugiyono. 2015. Metode Penelitian Kuantitatif, Kualitatif, dan R\&D. Bandung: Alfabeta.

Sujadi, Eko. (2018). Kode Etik Profesi Konseling Serta Permasalahan dalam Penerapannya. Tarbawi: Jurnal Ilmu Pendidikan, 14(2), 69-77. https://doi.org/10.32939/tarbawi.v14i2.298

Suryabrata, Sumadi. 1993. Mengatasi Rasa Cemas. Jakarta: PT Grafindo Persada.

Tohirin. 2012. Metode Penelitian Kualitatif dalam Pendidikan dan Bimbingan Konseling. Jakarta: PT Raja Grasindo.

Tomar, Shivani. 2013. The Psychological effects of Incarceration on inmates: Can we promote positive emotion in inmates. DELHI PSYCHIATRY JOURNAL. Vol 16(1), 66-72.

Widosari, Yuke Wahyu. 2010. Perbedaan Derajat Kecemasan dan Depresi Mahasiswa Kedokteran Preklinik dan Ko-asisten di FK UNS Surakarta. Skripsi (tidak diterbitkan). Surakarta: Universitas Sebelas Maret Surakarta.

Yin, Robert K. 2014. Studi Kasus Desain dan Metode. Jakarta: Rajawali Pers. 